\title{
Valeriy Grigorievich Savchenko: pioneering Russian hematologist: 8 January 1952-25 July 2021
}

\author{
Robert Peter Gale iD ${ }^{1,3^{凶}}$ and Grigory A. Efimov (D) ${ }^{2,3}$ \\ (C) The Author(s), under exclusive licence to Springer Nature Limited 2021
}

Bone Marrow Transplantation (2021) 56:2613-2614; https://doi.org/10.1038/s41409-021-01440-5

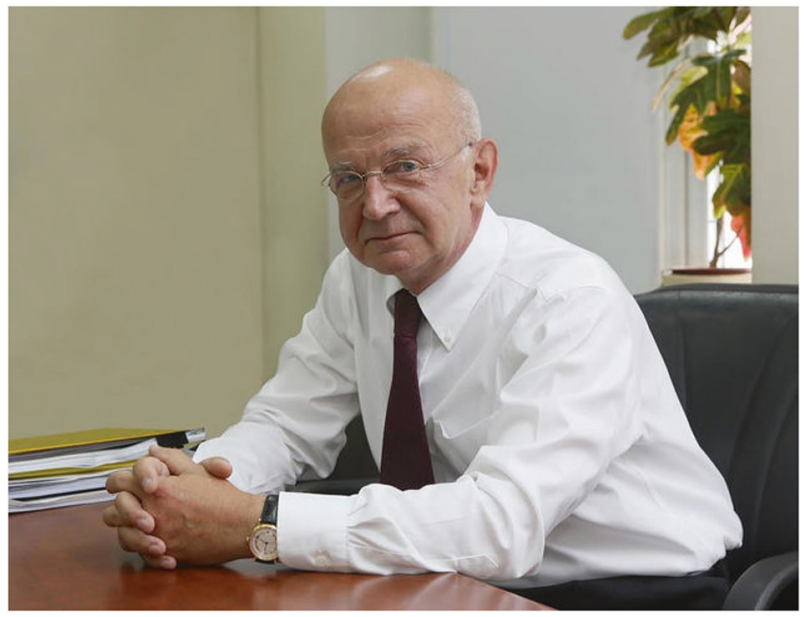

Valeriy Grigorievich Savchenko, a pioneering Russian hematologist and Director of the National Research Centre for Haematology, died unexpectedly on July 25,2021 , at his beloved country house in an historic place on the Ugra River $200 \mathrm{~km}$ south of Moscow, a dacha he built. Prof. Savchenko was a physician, researcher, mentor to many doctors and scientists, and a driving force in advancing therapy of hematologic cancers in Russia.

Valeriy Savchenko was born 8 January 1952 into a family of railroad engineers in Ukraine, then a republic of the Soviet Union. Food shortages post-WWII were common and his pregnant mother was sent to the small village of Karnaukhivka on the Dnieper River where her relatives had a cow.

Valeriy spent his childhood in Lviv until his father was promoted to Deputy Minister of Transportation of the USSR. and the family moved to Moscow. At age 15, unbeknownst to his parents, he applied for and was accepted into the Moscow School for Mathematics and Physics No. 2. The school was a venue for talented youth and an oasis of free-thinking in the otherwise controlled atmosphere of the Soviet Union. Students were taught by prominent scientists and mastered the natural sciences and humanities.

The expected path for alumni (Valeriy would later join the Board of his alma mater) was to continue their education in the natural sciences and many of Valeriy's classmates became successful scientists. However, Prof. Savchenko decided to dedicate himself to medicine applying to the 1st Moscow Medical Institute. From the start, he knew that he would specialize in hematology, its complexity fascinated him. He used to say hematologists are consulted when all other physicians give up.

Following graduation from the medical school Valeriy did his residency and Ph.D. studies at the Central Institute of Advanced Medical Studies under the supervision of Prof. Andrey Vorobiev, Chair of Hematology (Leukemia. 2020 34:2539-41). After defending his thesis on idiopathic thrombocytopenic purpura, Prof. Savcheko stayed on as a researcher working on plasma proteins and dialysis techniques. He combined his laboratory work with scientific editing at a medical journal and teaching to support his family. Prof. Savchenko's strong natural sciences background and extensive research career facilitated his staying abreast of modern biomedical science and shaped what later became his hallmark bringing the rigor of science to the bedside.

In 1987, Prof. Savchenko followed Prof. Vorobiev to the State Hematology Research Center of the Russian Academy of Medical Sciences, now the National Research Center for Hematology. He was followed by Prof. Elena Parovichnikova, his future wife and lifelong collaborator. Also in 1987, during the Perestroika period, Profs. Savchenko and Boris Afanasyev (Bone Marrow Transplant. 2020. 55:1882-3) spent 2 months studying haematopoietic cell transplants with Prof. E. Donnell Thomas (Leukemia. 2013. 27: 259) at the Fred Hutchinson Cancer Research Center in Seattle. On their return, they made it their goal to advance the nascent field of haematopoietic cell transplants in the Soviet Union and later Russia. In 1988, at age 33, Prof. Savchenko headed the Department for Chemotherapy of Hematological Cancer and Bone Marrow Transplantation at the National Research Center for Hematology. Prof. Savchenko achieved his goal: transplant results in Russia's leading institutions are now at the global standard.

Prof. Savchenko was a conduit of advances in international haematology to Russian physicians. In 1989, after the fall of the Iron Curtain, Prof. Vorobiev with the help of Prof. Savchenko hosted the first International Hematology Congress in Russia. The venue was Pushkinskiye Gory near Mikhaylovskoye where the great Russian poet Alexander Pushkin spent 2 years in exile and is buried. Amongst the speakers were Profs. Donald Pinkel, Emil J Freireich (Leukemia. 2021. 35:1812-3; Bone Marrow Transplant. 2021. 56:1768-9), Thomas Büchner (Leukemia. 2016. 30:2131-2), Dieter Hoelzer, Philip McGlave, Rolf Neth (Leukemia. 2020.

\footnotetext{
${ }^{1}$ Haematology Research Centre, Department of Immunology and Inflammation, Imperial College London, London, UK. ${ }^{2}$ National Research Center for Hematology, Moscow, Russia. This article is co-published in the journals Bone Marrow Transplantation and Leukemia https://doi.org/10.1038/s41409-021-01440-5 or https://doi.org/10.1038/s41375021-01407-x. ${ }^{\bowtie}$ email: robertpetergale@alumni.ucla.edu
} 
34:1717-8), RPG and others. The Congress started several close friendships and the long-lasting cooperation with global medical centres which Prof. Savchenko diligently cultivated.

In 1991, Profs. Parovichnikova, Büchner (with whom she had studied the previous year), Neth, and Hoelzer developed the idea of a Russian acute leukemia research group headed by Prof. Savchenko. The group has sponsored several multi-centre clinical trials and hosts an annual school for Russian hematologists: Acute Leukaemias and Lymphomas: Therapy and Research.

In 2010, Prof. Savchenko and colleagues started a National Society of Hematology which he chaired until his death. The Society organizes a biennial Russian Congress of Hematologists in close collaboration with the European Hematology Association (EHA). In 2011, Prof. Savchenko co-founded the Leukaemia Foundation, one of the most successful Russian charities funding therapy of adults with hematological diseases.

Prof. Savchenko's interests extended beyond haematopoietic cell transplants. He implemented several new therapies for hematologic cancers. In 1995, he introduced a program for pregnant women with acute leukemia to receive intensive chemotherapy thereby saving 81 babies lives. Another 2011 innovation was giving mesenchymal stromal cells to prevent graftversus-host disease (GvHD) and to treat septic shock. He was acutely interested in developing novel therapeutic approaches. His vision would continue to be the inspiration for future advances of his pupils.

Dr. Savchenko's career followed a stellar path. In 1993, he defended his habilitation thesis (equivalent to a DSc.): Modern strategy of therapy of acute leukemia. In 1996, he received the title of Professor of Medicine. In 2004, he became a Corresponding Member and in 2013, Academician of the Russian Academy of Science. Beginning in 2011 Prof. Savchenko headed the National Research Center for Hematology making it into one of the most successful medical institutions in Russia with an outstanding international reputation. He continued treating patients despite considerable administrative responsibilities and was celebrated by colleagues for his diagnostic skills and ability to think outside the box. He is succeeded in this position by Prof. Parovichnikova.

In 2003, a woman with Hodgkin lymphoma in the 3rd trimester of pregnancy developed severe neutropenia over a few hours.
A pathologist examining the bone marrow slide diagnosed acute leukemia. But after a brief deliberation Prof. Savchenko determined she had haemo-phagocytic syndrome from cytomegalovirus infection. Well-timed therapy saved the mother and child.

Professor Savchenko is survived by his wife, Prof. Elena Parovichnikova, and his son and daughter, Pavel and Sofia. He died too young. But as Anton Chekhov wrote: Где искусство, где талант, там нет ни старости, ни одиночества, ни болезней, и сама смерть вполовину... (Where art, where talent, there is no old age, no loneliness, no disease, and death itself is half...) We are much poorer without him.

\section{ACKNOWLEDGEMENTS}

RPG acknowledges support from the National Institute of Health Research (NIHR) Biomedical Research Centre funding scheme.

\section{AUTHOR CONTRIBUTIONS}

RPG and GAE prepared the typescript and contributed equally.

\section{COMPETING INTERESTS}

RPG is a consultant to BeiGene Ltd, Fusion Pharma LLC, LaJolla NanoMedical Inc., Mingsight Parmaceuticals Inc. CStone Pharmaceuticals, NexImmune Inc. and Prolacta Bioscience; advisor to Antengene Biotech LLC, Medical Director, FFF Enterprises Inc.; partner, AZCA Inc.; Board of Directors, Russian Foundation for Cancer Research Support; and Scientific Advisory Board: StemRad Ltd.

\section{ADDITIONAL INFORMATION}

Correspondence and requests for materials should be addressed to R.P.G.

Reprints and permission information is available at http://www.nature.com/ reprints

Publisher's note Springer Nature remains neutral with regard to jurisdictional claims in published maps and institutional affiliations. 